\title{
Study of color pigments associated to archaic chinchorro mummies and grave goods in Northern Chile (7000-3500 B.P.)
}

Marcela Sepúlveda ${ }^{1 *}$, Hélene Rousseliere ${ }^{2}$, Elsa Van Elslande ${ }^{2}$, Bernardo Arriaza $^{3}$, Vivien Standen ${ }^{4}$, Calogero M Santoro ${ }^{3,5}$ and Philippe Walter ${ }^{2}$

\begin{abstract}
This article presents the results of physical-chemical characterization of the layers of coating covering the bodies, faces and stuffed of four mummified human bodies and seven grave goods from the Chinchorro Archaic funerary tradition that inhabited the Atacama Desert of the far northern coast of Chile. Using Scanning Electron Microscopy with Energy-Dispersive X-Rays (SEM-EDX) and X-Ray Diffraction ( $\mu \mathrm{DRX}$ ), the study identified the use of different pigments including iron, manganese and copper oxides that were combined into different preparations or pictorial recipes for paste and coating bodies and faces. The results indicate that the Chinchorro, an archaic hunting, gathering and fishing society (7000- 3500 B.P.) managed a complex color technology for their mortuary practices.
\end{abstract}

Keywords: Pigment identification, Mummification, Color technology, Northern Chile, Chinchorro

\section{Introduction}

The Chinchorro Tradition extended from 7000 to 3700 BP, which corresponds to the Archaic Period in the Andeans Region. These hunting, gathering and fishing people inhabited Southern Peru and Northern Chile, living along the coast taking advantage of a wide and abundant range of coastal marine resources generated by the Pacific Ocean's cold Humboldt Current [1]. As they settled on particular coastal spots huge accumulation shell middens have enable us to construct their daily lives, while their extensive cemeteries, found on the slopes of coastal bluffs and within the domestic areas, contain multiple overlapping packaged burials. Studies of the Chinchorro funerary procedures began in the early 20th century and we now know that, in addition to having a specialized technology well suited to extracting coastal resources, these groups developed a variety of complex methods for treating and preserving the bodies of their deceased, including artificial mummification [2-4]. For 5000 years these people developed extensive knowledge of human anatomy and morphology,

\footnotetext{
*Correspondence: msepulveda@uta.cl

'Departamento de Antropología, Laboratorio de Análisis e Investigaciones Arqueométricas (LAIA), Universidad de Tarapacá, Arica, Chile Full list of author information is available at the end of the article
}

which they used to create their mummies, the first ever in human history [5]. The mummification techniques varied, both in terms of how they prepared, emptied and stuffed the dead bodies, and the application of different external finishes, and the latter feature has been used to classify the different funerary rites of these archaic coastal groups [6-8]. Three main forms of complex mummification have been identified among the Chinchorro: the Black Mummy Technique, the Red Mummy Technique and the Bandaged Mummy Technique. The Black Mummy Technique (ca. 7000-5000 BP) involved removing the organs, cleaning and reinforcing the skeleton then creating a clay mold of the body. Once the body was sculpted, the skin was replaced and painted over in a shiny black pigment. The face was covered with a clay mask painted in the same way. The Red Mummy Technique (4500- $4000 \mathrm{BP}$ ) differs from that of the black mummies in that each cavity of the body and head were emptied and then filled with a variety of materials (plant fiber, clay and feathers, among others). Once filled, the body was covered with red paint. A wig with long black hair was placed on the head of the deceased and kept in place with a blackcolored cap. The face was covered with a black mask. The bandaged mummies are a variant of the red ones in which the skin was wrapped on the body like bandages [9]. Unlike 
other mummification traditions around the globe [10,11], the Chinchorro mummified adults, infants, newborns and even fetuses. In short, in practicing mummification or "the materialization of death" [12], these coastal huntergatherers employed complex techniques to prepare the body and used a wide variety of materials available in their surroundings, including wood, plant fiber, animal skin and hair, ash, clay and pigments.

In this paper we will analyze the coating that covers artificially mummified bodies, one sample from stuffed of mummy, as well as the color that appears on items included among the grave goods that accompanied the bodies from different coastal sites (Figure 1). Specifically, four samples from a single black mummy and two red mummies were analyzed. Nine samples from Chinchorro grave goods are also analyzed in order to contrast these results with those obtained for the mummies. The samples were analyzed using Energy Dispersive X-Ray Spectroscopy (SEM-EDX) and Micro X-Ray Diffraction $(\mu \mathrm{XRD})$. Taken together, the data provide important technical information on the pigments used and shed light on their color technology, understood as knowledge set and productive processes to obtain the colors they used. It also contribute to debate symbolism, ritual practices and ceremonialism of the Chinchorro groups.

\section{Previous analysis}

Previous studies have used physical-chemical techniques to characterize certain elements and compounds used in the coating and stuffing of the Chinchorro mummies. Specifically, Energy-Dispersive-X-Ray-Fluorescence analysis (ED-XRF) was used to analyze the elements contained in the coating used on several mummified Chinchorro individuals [13-15]. In summary, the results indicated that more manganese was used in coating the red mummies (than the others), and this finding was confirmed by later Atomic Absorption Spectrometry (AAS) [16,17]. While these ED-XRF and AAS analyses helped to recognize the elements present in the coating, the techniques employed did not allow us to identify the type of manganese mineral used. Furthermore, the techniques used also required crushing of the samples, which prevented us from identifying the different minerals present in the paint in the case of mixtures. Additionally, it was not possible to identify layers beneath the surface coating, in the sense of differentiating the surface layer from possible underlying or priming layers that are macroscopically visible.

Another study of the gray sediments used to reshape or remodeled three black Chinchorro bodies and the internal filling and external surface of one mud-coated mummy was undertaken by [18]. Using a Scanning Electron Microscope (SEM) coupled with an Energy Dispersion Detector (EDS), the size and morphology of the clay compounds were identified. These results advanced our understanding of how malleable clays were used to construct the mummified bodies and functioned to preserve them. The absence of color pigments in these gray clays filling and the mud-coated mummy was also noted.

Lastly, continuing the emphasis on this type of compound, recent studies have addressed the chemical and mineralogical composition of the gray clay used as stuffing in the black mummies [13]. The results obtained from EDXRF, SEM-EDX and $\mu$ XRD analyses demonstrate that the clays are complex compositions based on quartz, albite, sanidine and muscovite occur naturally on the banks of rivers in the region. The gray clay was used to completely model the body including the face of the black mummies. The clay was collected and used in their natural state, without grinding or the addition of other compounds or color pigments.

In conclusion, for more than a decade different analytical techniques have contributed to study the different elements and compounds used in making the Chinchorro mummies. Despite the color analysis, however, the mineralogical nature of pigment from coatings and stuffed has still not been identified. Furthermore, the composition of the coatings must be distinguished from that of the stuffing. In other words, it is useful to specify whether the coatings correspond to a single layer of paint or several layers, as some authors have proposed before but without analytical or empiric proof $[19,20]$. Lastly, it is necessary to compare these compounds with those present in grave goods, so we can identify if and how these artifacts were associated with the materialization of the bodies themselves. More specifically, we understand the artifacts and bodies to be part of the same color technology production sequence, defined as the complete production process, from the procurement of the raw materials to their application on a support $[21,22]$. For this study, we ultimately chose to prioritize non-destructive techniques in order to preserve the samples for use in later analyses.

\section{Material and methods}

Two samples were extracted from the coating on the thorax of an adult male black mummy (Body 1) from the site of Maderas Enco (Maderos Enco C1; Figure 2a). The laboratory samples were labeled M.26 and M.27. Two other samples were taken from red mummies: Sample M.19 is from the coating on the mummified body of an infant (0-4 months) from the Morro 1 site (M1 Tomb 25, Body 5) (Figure 2b). Sample M.35 came from the head coating of an adult individual from the Playa Miller 8 site (PLM8 Cranium 1) (Figure 2c). A green sample obtained from the stuffing of a mummified infant (M.18) from the Estación Sanitaria site whose color had not been studied to date, was also analyzed (Figure 2d). Lastly, the analysis examined nine samples 


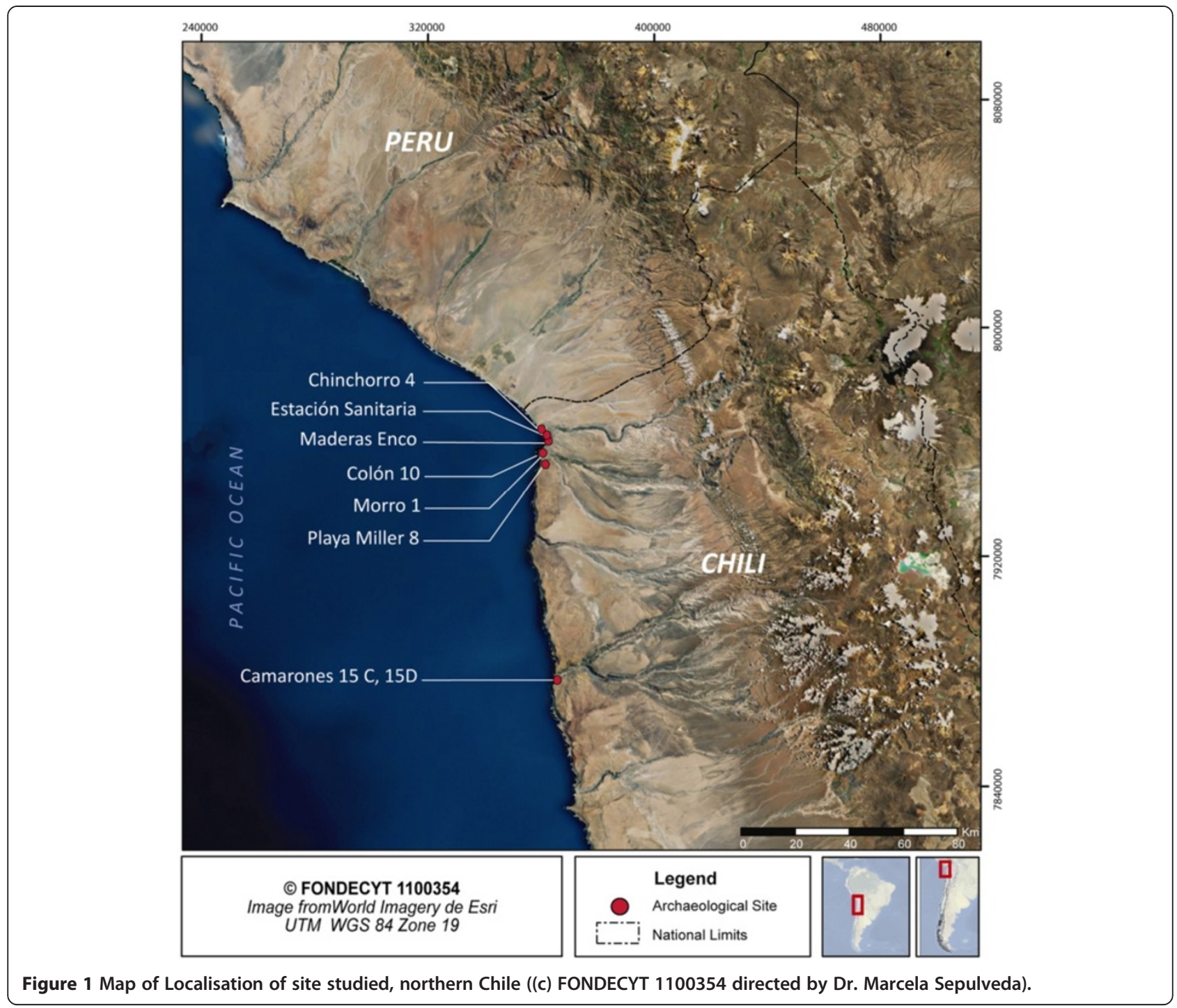

from red- and black-colored grave goods, as pigment in shell, powder in leather pouch or raw pigment, as pigment in shell or raw pigment (Table 1), in order to compare them with the results obtained from the bodies. All samples come from important burial sites located on the coastline. They correspond to the largest cemeteries of Archaic period in Andean Region.

The samples were collected and packaged, at the Archaeological Museum of the Universidad de Tarapacá in San Miguel de Azapa, before being shipped to the LAMS and C2RMF laboratories (Laboratoire d'Archéologie Moléculaire et Structurale, Université Pierre et Marie Curie in Paris; Centre de Recherche et de Restauration des Musées de France in Paris, respectively) in France.

In the lab, each sample was observed in sequence under a Nikon SMZ-10A binocular microscope and at different magnifications under a Nikon-Labophot (5X, 10X, 20X, 50X, 2- Xenon lamp, B-2A filter; excitation,
450 to $490 \mathrm{~nm}$; barrier, $520 \mathrm{~nm}$; dichroic mirror, $505 \mathrm{~nm}$ ) and a Scanning Electron Microscope (SEM, Philips XL $30 \mathrm{CP}$ ), using secondary electron (SE) and backscattered electron (BSE) modes.

After being observed front and back under an optical microscope, the samples were immersed in a resin (Resine Polyester SODY 33) for complementary observation and analysis. This kind of preparation is common in the identification and analysis of overlapping layers of paint primers and varnishes on historic paintings [23]. It has also been useful for analyzing parietal and rock painting [24]. In that state, the resins were polished on different surface carefully up to the edge of the sample then analyzed using the techniques proposed [25]. Then, we can observe stratigraphy of different samples. We also recognize the form and size of inclusions, differentiating big or large ones with size between 50 and $100 \mu \mathrm{m}$, from small under $20 \mu \mathrm{m}$. 


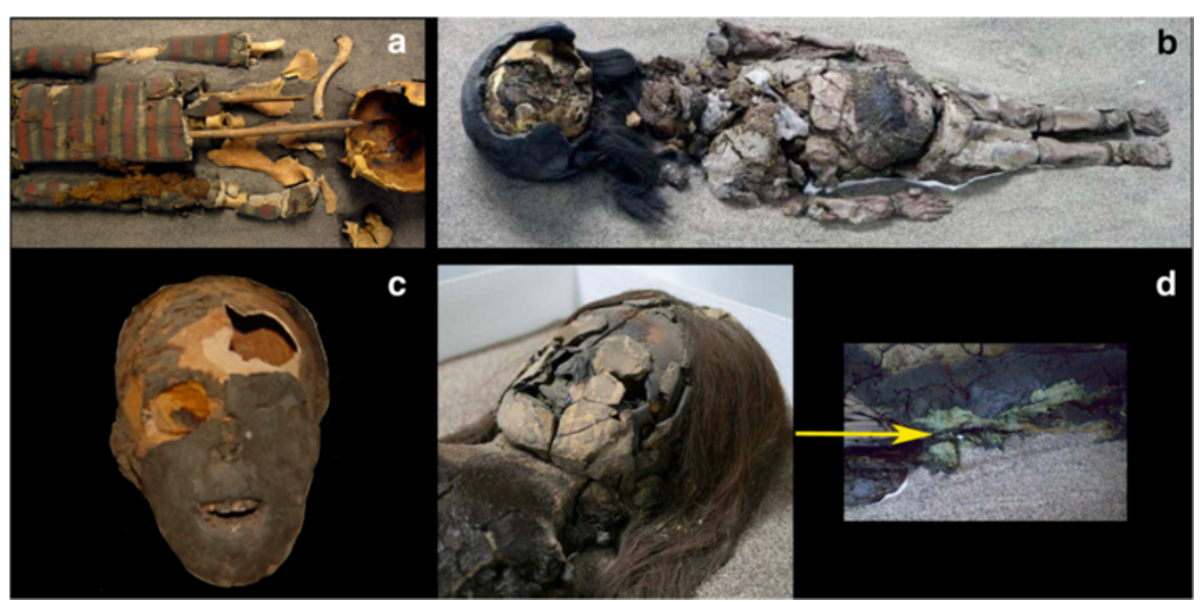

Figure 2 Sample from different kind of mummies. a) Maderas Enco; b) Morro 1; c) Playa Miller 8; d) Estación Sanitaria.

Afterwards, each sample was analyzed using Energy Dispersive Spectrometry (EDX) coupled with the SEM in order to obtain a qualitative identification of the elements present in the samples. The analyses were performed in BSE mode (20 KeV, 1000X-3000X), with both point and zonal identifications. Mapping of the most characteristic chemical elements in the sample was also performed to assess location and dispersion. To prevent any charging effect and obtain images with the highest resolution, each sample was covered with a fine layer of carbon. The INCA 4.15 program was used to acquire the data.

Lastly, the use of a Micro-Diffraction X-Ray device $(\mu \mathrm{DRX})$, an homemade system in the C2RMF, was used to identify the crystalline phases in the pigments. The device consists of a X-ray tube with a copper anode (wavelength of $\lambda=1.54186 \AA$ ), a Kirkpatrick-Baez optical system and a Rigaku R-Axis IV 2D detector imaging plate. The X-ray beam is collimated to a diameter of $250 \mu \mathrm{m}$, while an incident angle of 6 to $10^{\circ}$ enlarges the beam impinging the sample up to one millimeter. The diffracted X-rays are emitted in a $2 \theta$ cone and collected on the imaging plate, from which the diffractogram is extracted. The data were processed using the FIT2D program (http://www.esrf.eu/computing/scientific/FIT2D/), while identification of crystalline phases was performed using the EVA program (http://www.bruker-axs.de/eva.html). The analyzed thickness of the material depends on the weight on the elements: it is approximately $25 \mu \mathrm{m}$ when it is composed by low $\mathrm{Z}$ elements $(\mathrm{Al}, \mathrm{Si}, \mathrm{K})$ and

Table 1 Results of grave goods analyses by SEM-EDX and $\mu$ XRD

\begin{tabular}{|c|c|c|c|c|c|c|}
\hline Color & Sample & Site & Description & SEM-EDX & Grain shape & X-ray diffraction \\
\hline \multirow[t]{2}{*}{ Black } & M1 & CA15-C & Pigment in a shell & $\begin{array}{l}\mathrm{Mn}, \mathrm{Si}, \mathrm{Ca}, \mathrm{K}, \mathrm{Al} \\
\mathrm{Fe}, \mathrm{Mg}, \mathrm{Cl}, \mathrm{S}, \mathrm{Na}\end{array}$ & $\begin{array}{l}\text { Manganese crystals not clearly observed } \\
\text { (mixed with the other compounds) }\end{array}$ & $\begin{array}{l}\text { Cryptomelane, quartz, } \\
\text { anhydrite, calcite, diopside }\end{array}$ \\
\hline & M17 & $\begin{array}{l}\text { MO-1 Tumba } 25 \\
\text { Cuerpo } 5\end{array}$ & Pigment in a shell & $\begin{array}{l}\mathrm{Mn}, \mathrm{K}, \mathrm{Si}, \mathrm{Ca} \\
\mathrm{Cl}, \mathrm{Al}, \mathrm{P}, \mathrm{S}, \mathrm{Na}\end{array}$ & Manganese as 2-3 $\mu \mathrm{m}$ long grains & $\begin{array}{c}\text { Cryptomelane, halite, quartz, } \\
\text { calcite, albite }\end{array}$ \\
\hline \multirow[t]{7}{*}{ Red } & M1 & MASMA-1 & Raw Pigment & $\begin{array}{c}\mathrm{Fe}, \mathrm{Si}, \mathrm{Al}, \mathrm{Ca} \\
\mathrm{Cl}, \mathrm{Na} \text {, trace of } \mathrm{As}\end{array}$ & $\begin{array}{l}\text { Hematite spherical grains, } 10 \mu \mathrm{m} \text { in } \\
\text { diameter or ovoide grains ( } 1 \mu \mathrm{m} \text { thick) }\end{array}$ & Hematite, halite, kaolinite? \\
\hline & M8 & $\begin{array}{l}\text { CA15-C, } \\
\text { Cuerpo } 3\end{array}$ & Raw pigment & $\begin{array}{l}\mathrm{Fe}, \mathrm{Si}, \mathrm{Al}, \mathrm{Cl}, \mathrm{K} \\
\mathrm{S}, \mathrm{Na} \text {, trace of } \mathrm{As}\end{array}$ & $\begin{array}{l}\text { Hematite spherical grains, } \\
1 \mu \mathrm{m} \text { in diameter }\end{array}$ & $\begin{array}{l}\text { Hematite, goethite, halite, } \\
\text { quartz, calcite }\end{array}$ \\
\hline & M10 & COLON-10 & Pigment in a shell & $\begin{array}{c}\mathrm{Si}, \mathrm{Fe}, \mathrm{Ca}, \mathrm{S}, \mathrm{Al} \\
\mathrm{Cl}, \mathrm{K}, \mathrm{Na} \text {, trace of } \mathrm{As}\end{array}$ & Hematite ovoid grains, $1 \mu \mathrm{m}$ thick & $\begin{array}{l}\text { Hematite, quartz, } \\
\text { halite, anhydrite }\end{array}$ \\
\hline & M11 & MASMA & $\begin{array}{l}\text { Pigment on a } \\
\text { griding stone }\end{array}$ & $\begin{array}{l}\mathrm{Fe}, \mathrm{Si}, \mathrm{Ca}, \mathrm{Al} \\
\mathrm{Cl} \text {, trace of } \mathrm{As}\end{array}$ & $\begin{array}{l}\text { Hematite pherical grains, } 10 \mu \mathrm{m} \text { in } \\
\text { diameter or ovoide grains, } 1 \mu \mathrm{m} \text { thick }\end{array}$ & Hematite, halite, kaolinite \\
\hline & M13 & CA15-C & $\begin{array}{l}\text { Powder in a } \\
\text { leather pouch }\end{array}$ & $\begin{array}{l}\mathrm{Si}, \mathrm{S}, \mathrm{Fe}, \mathrm{Ca}, \mathrm{Al} \\
\mathrm{Cl}, \mathrm{Na} \text {, trace of } \mathrm{As}\end{array}$ & $\begin{array}{l}\text { Hematite cryslats with facets, } 2-7 \mu \mathrm{m} \\
\text { long and ovoid grains ( } 1 \mu \mathrm{m} \text { thick) }\end{array}$ & $\begin{array}{l}\text { Hematite, quartz, } \\
\text { calcite, halite }\end{array}$ \\
\hline & M14 & CA15-D & Raw pigment & $\begin{array}{l}\mathrm{Fe}, \mathrm{Si}, \mathrm{Al}, \mathrm{K}, \mathrm{Na} \\
\mathrm{Cl}, \mathrm{Ca} \text {, trace of } \mathrm{As}\end{array}$ & $\begin{array}{l}\text { Hematite spherical grains, } 10 \mu \mathrm{m} \text { in } \\
\text { diameter or ovoide grains ( } 1 \mu \mathrm{m} \text { thick) }\end{array}$ & $\begin{array}{l}\text { Hematite, halite, } \\
\text { diopside? illite? }\end{array}$ \\
\hline & M16 & $\mathrm{CHIN}-4$ & Raw pigment & $\begin{array}{l}\mathrm{Fe}, \mathrm{Si}, \mathrm{Al}, \mathrm{S} \\
\mathrm{P}, \mathrm{K}, \mathrm{Na}, \mathrm{Ca}\end{array}$ & Hematite ovoid grains, $1 \mu \mathrm{m}$ thick & $\begin{array}{l}\text { Hematite, gypsum, quarz, } \\
\text { halite, calcite? }\end{array}$ \\
\hline
\end{tabular}


about $5 \mu \mathrm{m}$ for heavy ones, like $\mathrm{Pb}, \mathrm{Hg}$. The geometry of the system is calculated using an alumina powder reference at the beginning of a series of measurements. The acquisition time for one measurement is of $5 \mathrm{mi}$ nutes. The spatial resolution of the system does not allow to characterize each layer on the samples crosssections because the thickness of the colored materials is less than the size of the beam. To have a higher spatial resolution, it is necessary to use other instruments at synchrotron radiation facilities [26].

\section{Results}

\section{Analysis of the coatings}

Sample 26 of the coating displays, from the outside in, 5 layers visible under binocular and optical microscopes (Table 2; Figure 3). These layers have similar compositions in terms of the type, size and shape of their components and inclusions, except for Layer 1 and the interfaces between layers 2-3 and 3-4. Layer 1 corresponds to a thin layer of red paint $(35 \mu \mathrm{m})$. Layer 2 (thin almost $90 \mu \mathrm{m}$ ) is brown in color, with large black inclusions within a brown matrix. Layer 3 (thin almost $180 \mu \mathrm{m})$ presents similar black inclusions, as well as large red inclusions in a light brown matrix. Layer 4 displays a more homogeneous composition in terms of the size and color of the inclusions, which are embedded within a brown matrix similar to the previous layer (thin of $175 \mu \mathrm{m}$ ). Lastly, layer 5 (thin almost $500 \mu \mathrm{m}$ ) also displays very large black and grey inclusions in a grayishblack matrix. One notable feature of this sample, found in the interfaces between layers 2 and 3 and 3 and 4, is the presence of very thin layers of yellow-colored pigment, which may be the remains of surface paint later covered over with the darker brown layers. This sample was only analyzed using $\mu \mathrm{DRX}$ in order to test the diffraction technique on this kind of sample. The diffractograms obtained during first analyses were difficult to read because of the heterogeneity of the sample and the variety of minerals present. Despite the difficulties, however, the presence of hematite was confirmed in all

Table 2 Descriptive of identified layers of M.26 (ARI- 8), from the surface to the coating

\begin{tabular}{|c|c|c|}
\hline Layer & Color & Thickness $(\mu \mathrm{m})$ \\
\hline 1 & Red & 35 \\
\hline 2 & Dark brown & 90 \\
\hline \multirow[t]{2}{*}{3} & Light brown & 180 \\
\hline & $\begin{array}{l}\text { On the surface of this layer we can observe } \\
\text { big yellow grain may be as an old decoration }\end{array}$ & \\
\hline \multirow[t]{2}{*}{4} & Light borwn & 175 \\
\hline & $\begin{array}{l}\text { On the surface of this layer we can observe } \\
\text { the same yellow grains from Layer } 3\end{array}$ & \\
\hline 5 & Grey-black & 500 \\
\hline
\end{tabular}

samples and is the primary component of the red surface layer. Other minerals identified included calcite, quartz and a little manganite $(\mathrm{MnOOH})$ (Figure 4). Lastly, the analysis identified a little cryptomelane $\left(\mathrm{KMn}_{8} \mathrm{O}_{16}\right)$, the manganese mineral used in the underlying brown layers observed under the binocular and optical microscopes. In some cases there is a higher proportion of cryptomelane and less hematite. Other peaks of diffractogram were not identified.

Microscopic observation of Sample 27 showed that 5 layers of coating are also present (Table 3). Elemental analyses were performed on the different layers of this sample using SEM-EDX. Subsequently, the elemental distribution was mapped using the same technique in order to assess co-localizations, such as potential associations between $\mathrm{Al}$ and $\mathrm{Si}$, among others. Layer 1, the outermost pigment layer (thin almost $20 \mu \mathrm{m}$ ), is composed of an aluminosilicate (co-localized $\mathrm{Si}$ and $\mathrm{Al}$ ). Lower layers of the coating (thin $170 \mu \mathrm{m}$ ) were composed of a material rich in manganese, mixed with maybe a clay $(\mathrm{Si}, \mathrm{Al}, \mathrm{K}, \mathrm{Mg}, \mathrm{Na})$ rich in iron oxides. Some grains of calcium (possibly calcite?) are at times co-localized with sulfur (gypsum?). In the layers of coating it is possible to distinguish different compositions based on the quantity and size of the manganese grains identified. In layer 2 , for example, the manganese primarily displays as large black grains, while layer 3 displays the largest amount of evenly distributed manganese, with grains that are generally smaller, although larger ones are also present. Thin of Layer 2 is almost $200 \mu \mathrm{m}$. Layer 4 (thin $340 \mu \mathrm{m}$ ) contains manganese but in this case the grains are small and evenly distributed, and large grains are much less abundant. Lastly, in layer 5 the manganese is much less abundant than in the other layers. We cannot obtain precise thinness for this layer. Using $\mu \mathrm{XRD}$, we identified the presence of crystalline manganese in the form of cryptomelane and manganite, as well as quartz. Also identified were albite, calcite and a little kaolinite. Some elements as $\mathrm{Fe}, \mathrm{S}$ and $\mathrm{Na}$ suggest the presence of a small amount of natrojarosite $\left.\left(\mathrm{NaFe}_{3}\left(\mathrm{SO}_{4}\right)_{2}(\mathrm{OH})_{6}\right)\right)$ [27].

Sample 19 (M.19) was difficult to prepare in resin. Observation under an optical microscope (white and ultraviolet light) showed that the sample consisted essentially of skin with a thickness of 350 to $450 \mu \mathrm{m}$. For the same reason the sample could not be analyzed using SEMEDX. DRX analysis showed the presence of hematite, quartz, calcite, albite and kaolinite, despite the difficulty in observing these compounds.

Under microscopic observation, Sample 35 (M.35) did not reveal a layer of surface paint, but a heterogeneous layer approximately $200 \mu \mathrm{m}$ thick was observed, composed of large black grains approximately $100 \mu \mathrm{m}$ long contained in a brown mixture of smaller sized black, red, white and translucent minerals. Also, no layer of 


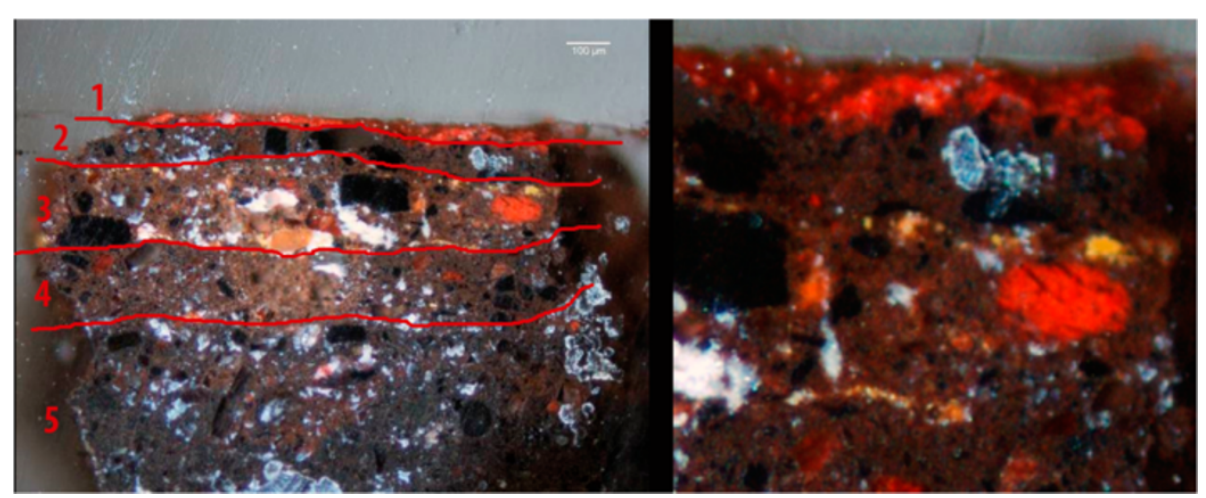

Figure 3 Transversal cut of M26. Observation by Optic Microscope.

paint was visible on the surface under SEM-EDX, and it is therefore likely that this individual's mask was not painted, but rather obtained its black color from the pigment contained in the molding placed over the face. The spectrum obtained by EDX indicates the co-localized presence of silica, aluminum and potassium, indicating that the sample may be a type of clay. Also observed were large grains of silica, possibly sand, and a compound rich in iron and sulfur. $\mu \mathrm{DRX}$ analysis confirmed the presence of cryptomelane, hematite, quartz, calcite, halite, albite and kaolinite. A jarosite mineral, probably natrojarosite, was also identified, but should be interpreted cautiously until it can be confirmed.

In general, the samples analyzed display similar characteristics in terms of shape and chemicals composition. The size and relative proportion of the minerals do vary, as observed in the sample slices and as indicated in the results previously obtained through EDXRF and AAS. One notable finding is that samples M.26 and M.27 (coming from a black mummy coating) empirically prove the presence of several overlapping layers of coating. These coatings are composed of a clay material (with quartz, calcite, albite, kaolinite and calcium sulfate) and a compound rich in manganese (cryptomelane and manganite). The relative proportions of these two main constituents varies from layer to layer, as does the size the inclusions, and it therefore follows that they are different preparations made with the same raw materials. Notable in the case of Sample M.26 are the two interfaces between layers 2-3 and 3-4, which could be interpreted as decorations applied before repainting. The layer of red pigment on the surface corresponds to the decoration

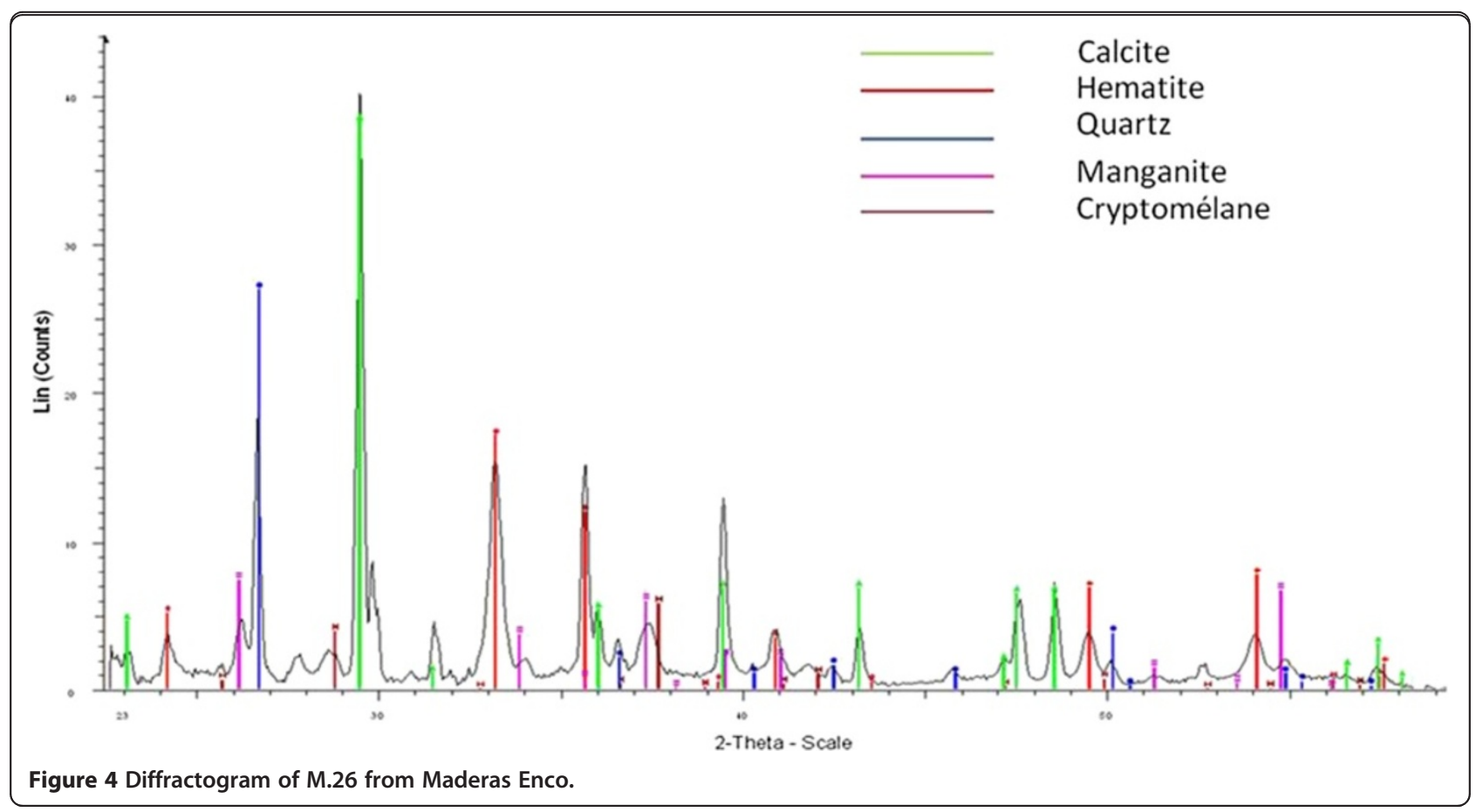


Table 3 Descriptive of identified layers of M.27 (ARI- 9), from the surface to the coating

\begin{tabular}{clc}
\hline Layer & Color & Thickness $(\boldsymbol{\mu m})$ \\
\hline $\mathbf{1}$ & White-yellow & 20 \\
$\mathbf{2}$ & Dark brown & 170 \\
$\mathbf{3}$ & Light brown & 200 \\
$\mathbf{4}$ & Light brown & 340 \\
$\mathbf{5}$ & Layer not very attached, difficult to analyse & - \\
\hline
\end{tabular}

currently visible; but this layer is very fragile and comes off easily.

Sample M.19 confirms that the surface coatings with paint might have been applied directly on the skin, as usually observed among the red mummies. Nevertheless, the layer is very fragile and most of it seems to have come off already. Sample M.35 shows that, despite the change in the mummification style from black to red, the technological tradition that produced the blackcolored paint is indistinguishable between these two forms of mummification. These are pictorial mixtures that contain the same minerals and share the same production process, and they seem to have remained the same over time despite the fact that the black color, which initially was applied over the entire body, eventually was limited to the head alone.

\section{Analysis of the stuffing}

The only stuffing (M.18) analyzed in this study is greencolored sand. Observation of the sample displays the presence of grains of different colors and sizes, despite our characterization of the grains as "green." SEM-EDX analysis demonstrates the presence of different elements such as sulfur, chlorine, copper, calcium and potassium (Figure 5). $\mu \mathrm{DRX}$ analysis indicates the presence of quartz, possibly sand and atacamite. This identification is particularly important, as the use of copper mineral has not previously been identified in the region for Archaic period. We cannot rule out that it may have been extracted from mines unknown to date, as copper comes from specific places and this mineral is not present in all the Atacama Desert. It may also have come from exchanges with people having access to mines located in what is now southern Peru, or those located $300 \mathrm{~km}$ South of our area of study, where metallurgical productions indicate that copper mines were operating in the $15^{\text {th }}$ and $16^{\text {th }}$ centuries [28]. While the identification of copper minerals on Chinchorro mummies has been recognized previously [29], the analytical identification presented herein is something new, as it demonstrates the existence of the search for copper-based minerals during the Archaic period, much earlier than what has previously been thought [30].

\section{Analysis of the grave goods}

Nine samples from a variety of black $(n=2)$ and red $(\mathrm{n}=7)$ objects from different sites as Morro 1 (Mo-1), Colon 10, Chinchorro 4 (CHIN-4) and Camarones 15 (CA15-C and CA15-D) were analyzed (Table 1). Black was less frequently present on the objects, and found in the interior of shells (Figure 6a and 6b). Red was found as a raw material inside leather pouches, or as a raw material (Figure 6c and 6d). It was also identified inside mortars and shells that were used as containers, or possibly for mixing.

Under SEM-EDX, the black color is primarily indicative of the presence of manganese moreover, other elements were found such as $\mathrm{Si}, \mathrm{Ca}, \mathrm{Al}$ and $\mathrm{Na}$. One distinctive element identified was $\mathrm{Fe}$, which was found in Sample 1 (M.1) at CA15-C. A difference was found in Sample M.17 from Mo-1, which doesn't contain Fe but present $\mathrm{P}$. Another difference observed was the identification of a manganese compound in the form of 2 to $3 \mu \mathrm{m}$ needles embedded in layers of clay (Table 1 ). $\mu \mathrm{DRX}$ analysis determined that these elements correspond to cryptomelane, along with quartz, calcite and a variety of salts (anhydrite and halite, among others). The two samples correspond to paint adhered to the walls of a shell used as a container, and thus they are understood to be components of different compounds; however, some of the quartz and salts may correspond to sediments from the place where the object was found.

In regard to the red color, SEM-EDX analyses indicate the presence of iron above all. In certain cases other elements such as silica, aluminum, potassium, magnesium, sulfur and calcium can also be observed. In all cases except CHIN-4, there was a minor amount of arsenic, an element naturally occurring in watercourses in the region [31]. More interesting still is the presence of iron with different morphologies. A series of samples (M1 from MASMA, M11 from MASMA-1 and M14 from CA15-D) were identified as containing iron in large spheres approximately $10 \mu \mathrm{m}$ in diameter and ovoid spheres of $1 \mu \mathrm{m}$ (Figure 7). Other samples (M8 from CA15-C, M10 from COLÓN 10 and M16 from CHIN-4) displayed iron in $1 \mu \mathrm{m}$ spheres. Lastly, in a single case (M13 from CA15-C) angular grains 2 to $7 \mu \mathrm{m}$ long and spheres $1 \mu \mathrm{m}$ in diameter were also observed. Through $\mu \mathrm{DRX}$ analysis it was determined that in all cases the mineral in question was hematite, combined with different types of other minerals: halite, calcite and gypsum (Figure 8). Other peaks of diffractogram were not identified.

\section{Discussion}

Results obtained from the analysis of the coatings applied to the mummies indicate that the mummies were painted several times, as we observed different 


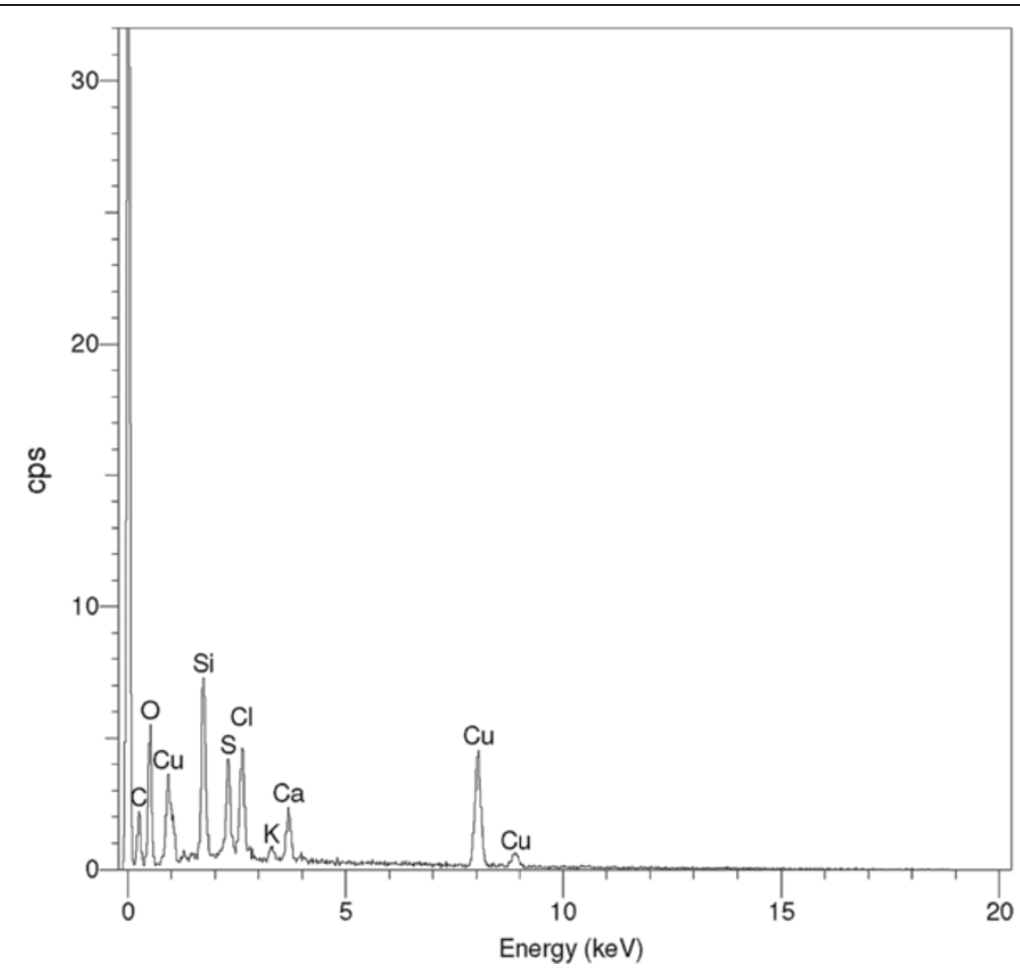

Figure 5 Spectrum of M.19 by SEM-EDX.

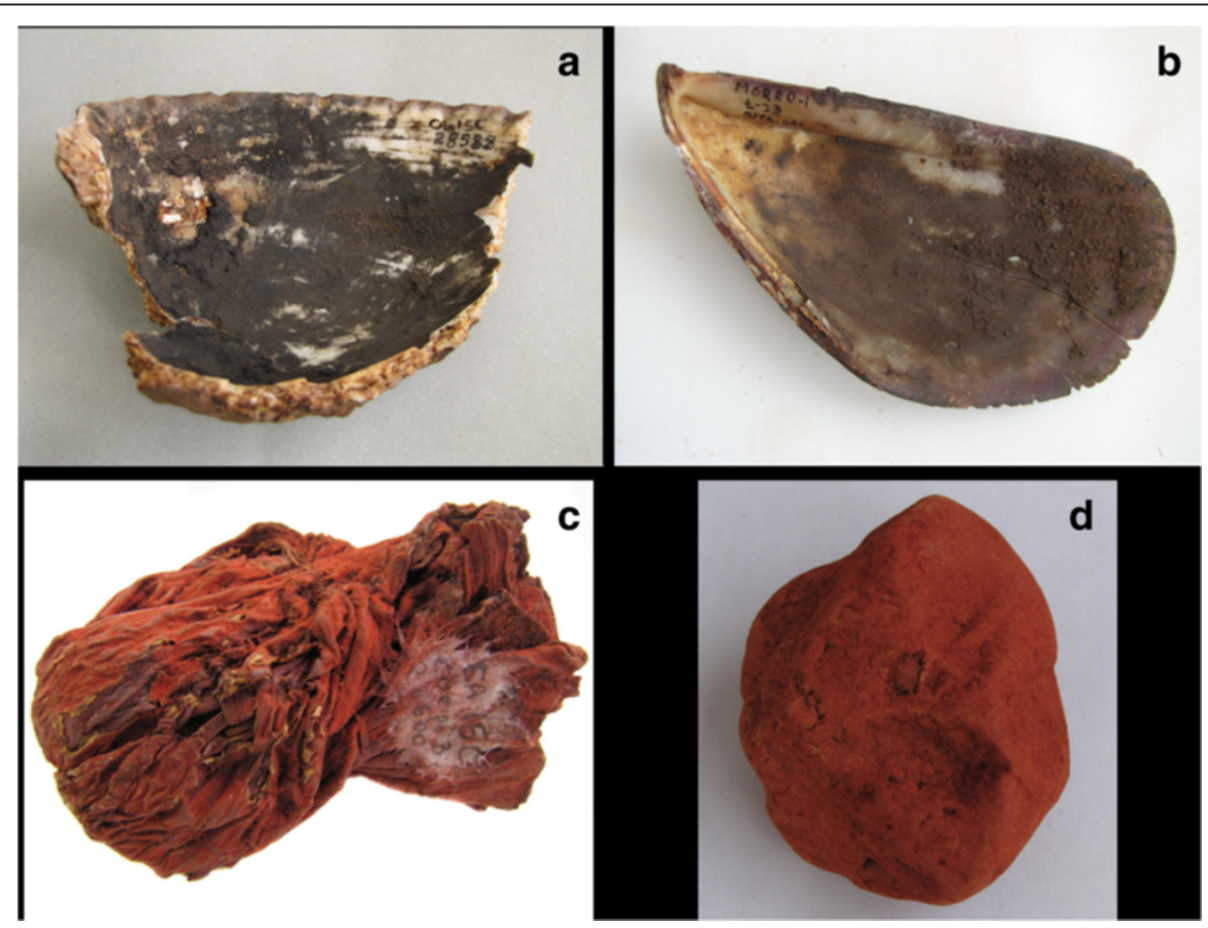

Figure 6 Sample from different grave goods. a) Camarones 15C; b) Morro 1; c) Camarones 15C; d) Masma. 


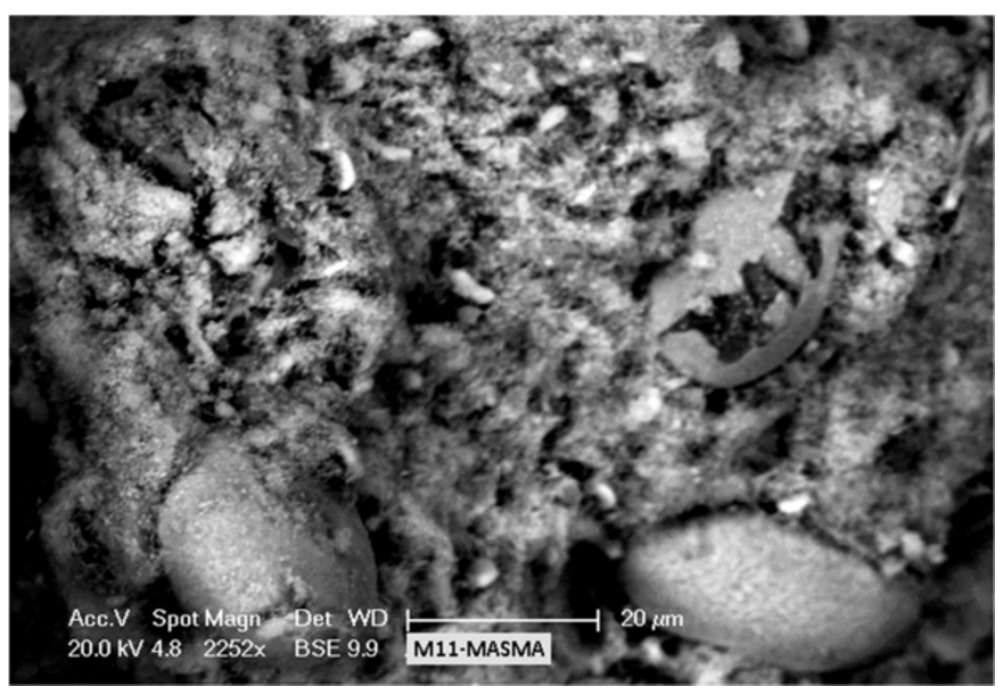

Figure 7 Image by SEM.

painting layers. This empirical evidence could be interpreted in one of two ways: either the mummified bodies were not buried until they were fully materialized and several layers of paints were applied or they were buried and exhumed and painted from time to time. The uncertainty arises from the difficulty in determining whether the repainting occurred at the time the individual was mummified and while the body remained for some time among the living, or whether subsequent repainting was part of the funerary trajectory that required exhumation. We think that constant action of exhumation would have affected the condition of these fragile effigies, which is not the situation. Whatever the case, the action of repainting reaffirms the special attention that was paid to these materialized bodies, and this same attitude is also observed in the intentional repair of other mummies. The

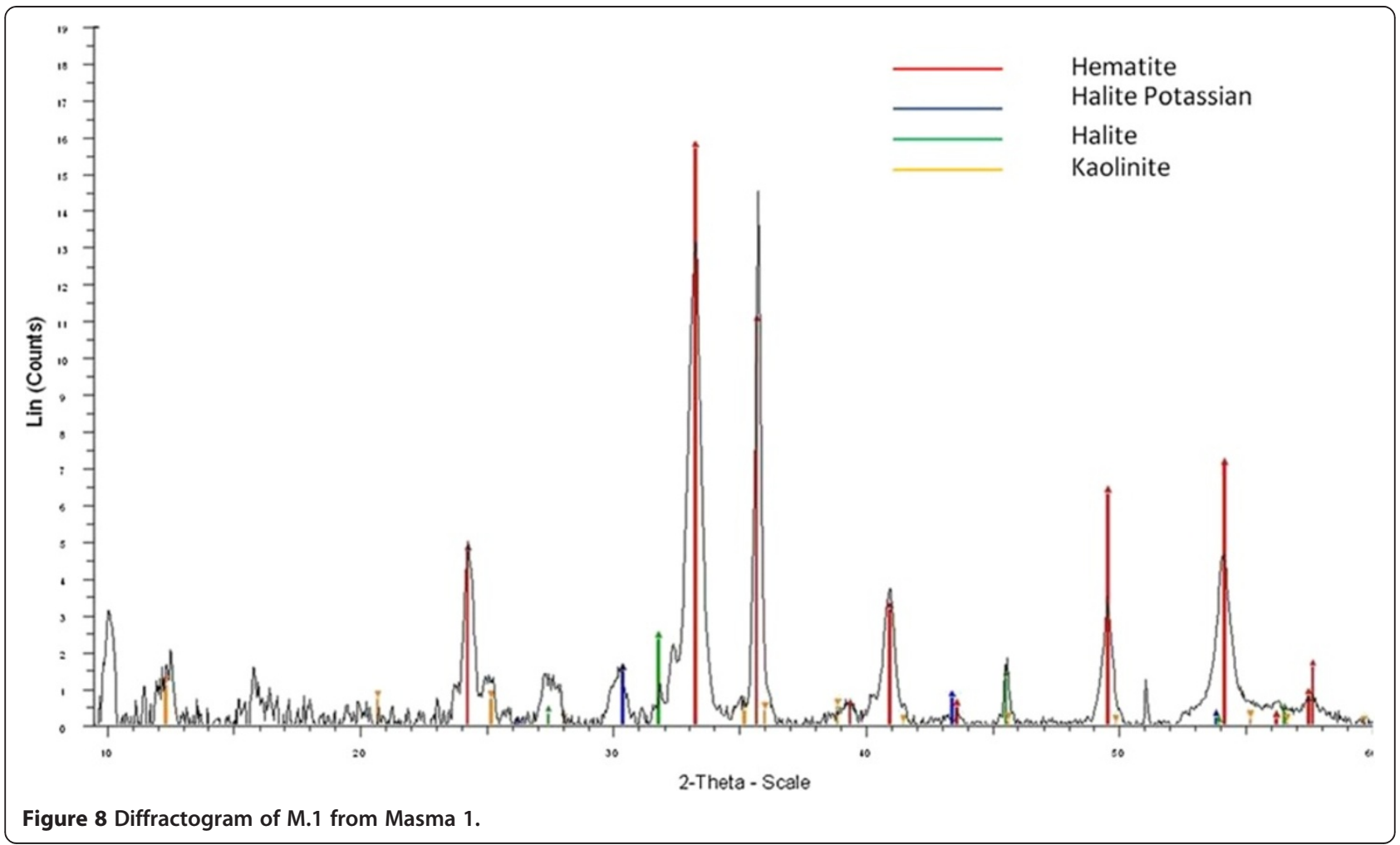


identification of the raw materials sheds light on the Chinchorro people's knowledge of how to procure and prepare these materials. Despite the changes in the use of black color on the mummified bodies, from all the body in Black Mummies to head only in Red Mummies, the mixtures used remained for a long time.

Pigment analysis of the grave goods identified minerals similar to those specified on the mummified bodies, hematite and cryptomelane which had not be identified until now as previous studies had been only elemental [13-15]. As the hematite of the coast are different from those found in the highlands of this region [31], these may have come from different supply sites. Nevertheless, the identification of cryptomelane is particularly interesting, as the sources of this mineral are found above 4500 meters of altitude [22]. This finding allows us to formulate interesting hypotheses about how the archaic hunting and fishing people of the coast may have journeyed to the highlands themselves or traded with highland hunter-gatherers to obtain this material [22]. But we need to know more about the other hunter gatherer tradition development of archaic period to understand their possible exchange. Pigment analysis open the possibility to study economic side of this hunter gatherer from this Andean region.

From a technological perspective, the results obtained confirm that the coastal Chinchorro people had specific knowledge of pictorial recipes. The fact that pigments and clays were combined to make the paint that was then used to coat the mummies also points to specific knowledge of the raw materials used, particularly the plastic or additive qualities of the clays and the coloring strength of the manganese and iron minerals. Effectively, the Chinchorro artisans selected and carefully mixed these raw materials to obtain the desired colors, knowing how much of each material to use, how finely to grind them, and how to combine them. The results also suggest that they knew the source of the raw materials used in their preparations, some of which were located hundreds of kilometers away, as for example for cryptomelane.

In productive terms, the objects analyzed show the pigments in stages prior to its application on the bodies. Once the colored raw material was obtained, it was no doubt ground up and then stored as a powder or mixed with other compounds. The powder present inside the leather pouch corresponds to such a preliminary stage, while the lumps found correspond to another way of storing the pigment-mixed with clay compounds. The pigment or mixture could then be mixed again with water, for example, to liquefy it into a paint that could then be applied as a coating on the mummified bodies. Thus, the objects and the bodies analyzed display different stages of the same color production sequence. These results tell us something of the Chinchorro's knowledge of color, from its procurement to application and even preservation. But we still do not know why, in the entire Andean area, only the Chinchorro people employed such color technology for mummifying their dead or to materialize bodies during the archaic period. To date, there is also no consensus about the origin of Chinchorro mummification practices or the origin of these coastal peoples themselves [8,32].

In terms of funerary rites, the analysis confirmed that the mummified bodies were not buried or abandoned once the mummification process was complete. On the contrary, this long and laborious effort was part of a more prolonged ritual use and consumption, which would have involved the deterioration of the outermost layer of the coating. In social terms, the 'materialization of death' through the mummification of the bodies shows a degree of specific knowledge and careful, timeconsuming preparation indicative of the presence of "mummification experts". The practice seems to have developed primarily in the Late Archaic period when the coastal population increased, perhaps in association with climate changes and increasing water ressources that occurred at the end of the Middle Archaic [1,4]. Also, Chinchorro artificial mummification was triggered by arsenic poisoning and grief [7]. Arseniasis causes premature birth, stillbirth, spontaneous abortion and high perinatal dead, so Chinchorro parents facing high mortality rate of their babies (fetuses and newborns) started to preserve the tiny bodies to assuage their emotional grief. Mummification was a synergy between environmental constraints, grief, ideology and the afterlife.

Moreover, after the beginning of mummification process, the identification and use of different pigments may point to incipient social distinctions among the Chinchorro. Reviewing the chronology of the different types of mummification shows that one kind did not replace another, but rather, the black mummies were somewhat contemporary with the red ones, and the red ones with the natural mummies, although in general the black ones tend to be older than the red ones [33]. Limiting the application of black color to the heads of the mummies, which occurred later, may have been related to the availability of the raw material, in this case manganese, although the same may be said about the different forms of hematite and cooper minerals. Nevertheless, changes in the Chinchorro's mummification techniques can be also related to variation in social dimension of this group, specifically with ideological and/or symbolic sphere with aesthetic connotations. This may mean that access to and use of certain pigments was restricted to certain individuals, including fetus and children, especially if these minerals were difficult to obtain. Therefore, it is possible that the knowledge of color technology and of how to prepare the mummified bodies was in the hands of experts 
and was only available to certain individuals who enjoyed privileges within their group. The discovery of an adult individual with advanced osteoarthritis (as shown by deformities and joint immobility) with its head painted with iron oxide indicates that the members of the group treated this individual carefully both during life and after death [34]. In other words, certain individuals with specific roles or status in life would have enjoyed similar treatment in death. Similarly, the scarcity of green color and scant use of copper minerals may suggest that these minerals were reserved for certain individuals.

Arriaza [4] argues that to understand the social dynamic of artificial mummification among Chinchorro the practice should be analyzed from the trilogy of the grieving individuals, the dead and the conception of the spiritual world. The author also affirms that artificial mummification was a central component of rituals that reintegrated both the grieving individuals into the real world and the deceased person (transformed into a mummy) into the spiritual world. He proposes that, once they were completed and adorned, the mummies became part of the world of the ancestors, and would have been venerated and cared for as such. In this regard, our analyses provide technical information to support the care that the ancient Chinchorro people showed for their mummified deceased.

\section{Competing interests}

The authors declare that they have no competing interests.

\section{Authors' contributions}

MS and PW coordinate the study. MS, HR and EV performed all analysis by SEM-EDX and $\mu$ XRD. BA, VS and PW defined Chinchorro mummies sampling and collected sample. MS, PW and CS edited and prepared the first version of the text. All the authors have read and approved the final manuscript.

\begin{abstract}
Authors' information
MS Associate Professor and researcher, Departamento de Antropología and Director of Laboratorio de Análisis e Investigaciones Arqueométricas (LAIA), Universidad de Tarapacá. Doctorated from Université París 1- Panthéon Sorbonne. HR Research assistant, Laboratoire d'Archéologie Moléculaire et Structurale (LAMS), CNRS-UMR 8220- Université Pierre et Marie Curie (UPMC). Graduated from Université de Bordeaux. EV Research assistant, Laboratoire d'Archéologie Moléculaire et Structurale (LAMS), CNRS-UMR 8220- Université Pierre et Marie Curie (UPMC). Graduated from Université de Technologie de Compiène. BA Full Professor and researcher, Instituto de Alta Investigación, Universidad de Tarapacá. Doctorated from Arizona State University. VS Associate Professor and researcher, Departamento de Antropología, Universidad de Tarapacá. Doctorated from Universidad Nacional Autónoma de México. CS Full Professor, Instituto de Alta Investigación, Universidad de Tarapacá; Researcher Centro de Investigaciones del Hombre en el Destiero (CIHDE). Doctorated from University of Pittsburg. PW Researcher Director CNRS and Director of Laboratoire d'Archéologie Moléculaire et Structurale (LAMS), CNRS UMR 8220- Université Pierre et Marie Curie (UPMC). PhD from Université Paul Sabatier- Toulouse III.
\end{abstract}

\section{Acknowledgment}

This work was part of a France- Chilean cooperation and supported under the grant ECOS-CONICYT CO9-H03: Caracterización físico- químico de los "nano-cosméticos" utilizados en las momias de la cultura Chinchorro del extremo norte de Chile and FONDECYT 1100354. We also would like to thank to MECESUP UTA 0801 and Convenio de Desempeño Universidad de Tarapacá- MINEDUC.

\section{Author details}

'Departamento de Antropología, Laboratorio de Análisis e Investigaciones Arqueométricas (LAIA), Universidad de Tarapacá, Arica, Chile. ${ }^{2}$ Laboratoire d'Archéologie Moléculaire et Structurale), Université Pierre et Marie Curie, CNRS-UMR 8220, Paris, France. ${ }^{3}$ Instituto de Alta Investigación, Universidad de Tarapacá, Arica, Chile. ${ }^{4}$ Departamento de Antropología, Universidad de Tarapacá, Arica, Chile. ${ }^{5}$ Centro de Investigaciones del Hombre en el Desierto (CIHDE), Arica, Chile.

Received: 17 July 2013 Accepted: 28 January 2014

Published: 4 March 2014

\section{References}

1. Marquet P, Santoro C, Latorre C, Standen V, Abades S, Rivadeneira M, Arriaza B, Hochberg M: Emergence of social complexity among coastal hunter-gatherers in the Atacama Desert of northern Chile. Ment Health Nurs 2012, 109(37):14754-14760.

2. Uhle M: La arqueologia de Arica y Tacna. Boletín de la Sociedad Ecuatoriana de Estudios Históricos Americanos 1919, 3(7-8):1-48.

3. Allison M, Focacci G, Arriaza B, Standen V, Rivera M, Lowenstein J: Chinchorro, momias de preparación complicada: métodos de momificación. Chungara Revista de Antropología Chilena 1984, 13:155-173.

4. Santoro C, Rivadeneira M, Latorre C, Rothhammer F, Standen V: Rise and decline of Chinchorro sacred landscapes along the hyperarid coast of the Atacama Desert. Chungara Revista de Antropología Chilena 2012, 44(4):637-653.

5. Arriaza B: Cultura Chinchorro. Las momias artificiales más antiguas del mundo. Santiago de Chile: Editorial Universitaria; 2003.

6. Arriaza B: Tipología de las momias Chinchorro y evolución de las prácticas de momificación. Chungara Revista de Antropología Chilena 1994, 26:11-24.

7. Arriaza B: Chinchorro bioarchaeology: chronology and mummy seriation. Lat Am Antiq 1995, 6:35-55.

8. Standen V: Temprana complejidad funeraria de la Cultura Chinchorro (Norte de Chile). Lat Am Antiq 1997, 8:134-156.

9. Arriaza B, Standen V, Cassman V, Santoro C: Chinchorro Culture: Pioneers of the Coast of the Atacama Desert. In Handbook of South American Archaeology. Edited by Silverman H, Isbell W. New York: Springer; 2008:45-58.

10. Goren Y, Nigel Goring-Morris A, Segal I: The technology of skull modeling in the Pre-Pottery Neolithic B (PPNB): regional variability, the relation of technology and iconography and their archaeological implications. J Archaeol Sci 2001, 28:671-690.

11. Dodson A, Ikram S: Mummy in ancient Egypt: Equipiing the Death for eternity. New York: Thames \& Hudson/Le Caire: AUC Press; 1998

12. Fahlander $F$, Oestigaard $T$ : Chapter 1: The materiality of death: bodies, burials, beliefs. In The materiality of death: bodies, burials, beliefs. Oxford: Archaeopress; BAR International Series 1768; 2008.

13. Arriaza B, Cornejo L, Lienqueo H, Standen V, Santoro C, Acarapi J: Caracterización elemental de arcillas utilizadas en la momificación artificial de la Cultura Chinchorro, extremo norte de Chile, mediante espectrometría de fluorescencia de rayos-X de energía dispersiva (EDXRF), Anales del X. Seminario Latinoamericano de análisis por Técnicas de Rayos X. Arica: Universidad de Tarapacá-CIHDE; 2006:1-7.

14. Arriaza B, Cornejo L, Lienqueo H, Standen V, Santoro C, Acarapi J: Caracterización química de las arcillas utilizadas para la momificación artificial en la Cultura Chinchorro, extremo Norte de Chile. In Mummies and Science. World Mummies Research. Edited by Atoche P, Rodríguez C, Ramírez M. Santa Cruz de Tenerife: Academia Canaria de la Historia; 2008:515-520.

15. Arriaza B, Cornejo L, Lienqueo H, Standen V, Santoro C, Guerra N, Hoesen JV, Santos M: Caracterización química y mineralógica de los materiales grises de los cuerpos Chinchorro modelado. Chungara Revista de Antropología Chilena 2012, 44:177-194.

16. Mella U: Caracterización Química de las Pátinas Negras presentes en el Casco y Mascarilla de las Momias Rojas de la Cultura Chinchorro, Undergraduate thesis. Arica, Chile: Chemistry Department, Universidad de Tarapacá; 2007.

17. Gutiérrez S: Caracterización Química de las Pátinas Negras utilizadas en la Momificación de las Momias Negras de la Cultura Chinchorro, Undergraduate thesis. Arica, Chile: Chemistry Department, Universidad de Tarapacá; 2007. 
18. Van Hoesen J, Arriaza B: Characterizing the micromorphology of sediments associated with Chinchorro mummification in Arica, Chile using SEM and EDS. Archaeometry 2011, 53(5):986-995.

19. Bird J: Excavations in Northern Chile. New York: American Museum of Natural History; Serie Anthropological papers of the American Museum of Natural History 38(4); 1943

20. Bittmann B: Revisión del problema Chinchorro. Chungara Revista de Antropología Chilena 1982, 9:46-79.

21. Sepúlveda M: Pinturas rupestres y tecnología del color en el extremo sur de Chile. Magallania 2011, 39(1):195-212.

22. Sepúlveda $M$, Valenzuela $D$, Cornejo L, Lienqueo C, Rousselière H: Óxidos de manganeso en el extremo norte de Chile: en torno al abastecimiento, producción y movilidad del color negro durante el período arcaico. Chungara Revista de Antropología Chilena Revista de Antropología Chilena 2013, 45(1):141-157.

23. De Viguerie $L$, Walter $P$, Laval $E$, Mottin $B$, Solé V: Revealing the sfumato Technique of Leonardo da Vinci by X-Ray Fluorescence Spectroscopy. Angew Chem Int Ed 2010, 49(35):6125-6128.

24. Chalmin E, Menu M, Vignaud C: Analysis of rock art painting and technology of Palaeolithic painters. Meas Sci Technol 2003, 14:1590-1597.

25. Wachowiak M: Efficient new methods for embedding paint and varnish samples for microscopy. J Am Inst Conserv 2004, 43(3):205-226.

26. Welcomme E, Walter P, Bleuet $P$, Hodeau JL, Dooryhée E, Martinetto $P$, Menu M: Classification of lead white pigments using synchrotron radiation micro X-ray diffraction. Applied Physics A 2007, 89:825-832.

27. Sepúlveda M, Gutierrez S, Campos-Vallette M, Clavijo E, Walter P, Carcamo J: Raman spectroscopy and X-ray fluorescence in molecular analysis of yellow blocks from the archeological site Playa Miller 7 (northern Chile). J Chil Chem Soc 2013, 58(3):1651-1654.

28. Zori C, Tropper P, Scott D: Cooper production in late prehispanic northern Chile. J Archaeol Sci 2012:1-11. http://dx.doi.org/10.1016/j.jas.2012.09.012.

29. Bittman B, Munizaga J: Algunas consideraciones en torno al Complejo Chinchorro (Chile), Actas del VII Congreso de Arqueología Chilena, Volume 1. Altos de Vilches, Chile: Ediciones Kultrún; 1977:119-130.

30. Figueroa V, Salazar D, Salinas H, Núñez-Regueiro P, Manriquez G: Pre-hispanic mining ergology of northern Chile: an archaeological perspective. Chungara Revista de Antropología Chilena 2013, 45(1):61-81.

31. Sepúlveda M, Laval E, Cornejo L, Acarapi J: Elemental characterization of prehispanic rock art and arsenic in northern Chile. Rock Art Research 2012, 29(1):93-107.

32. Arriaza B, Doubrava M, Standen V, Haas H: Differential mortuary treatment among the Andean Chinchorro fishers: social inequalities or In Situ regional cultural evolution? Curr Anthropol 2005, 46(4):662-671.

33. Standen V, Santoro C, Arriaza B: Síntesis y propuesta para el periodo Arcaico en la costa del extremo norte de Chile. Chungara Revista de Antropología Chilena 2004, 36:201-212. Tome I.

34. Silva- Pinto V, Valenzuela D, Sepúlveda M: Osteaortrosis poliarticular en Chinchorro. Revisión de un caso y discusión sobre el autocuidado en la prehistoria de Arica, norte de Chile. Rev Med Chil 2013, 141:644-650.

doi:10.1186/2050-7445-2-7

Cite this article as: Sepúlveda et al:: Study of color pigments associated to archaic chinchorro mummies and grave goods in Northern Chile (7000-3500 B.P.). Heritage Science 2014 2:7.

Publish with ChemistryCentral and every
scientist can read your work free of charge
"Open access provides opportunities to our
colleagues in other parts of the globe, by allowing
anyone to view the content free of charge."
\[ \text { W. Jeffery Hurst, The Hershey Company. } \]
- available free of charge to the entire scientific community
- peer reviewed and published immediately upon acceptance
- cited in PubMed and archived on PubMed Central
- yours - you keep the copyright
submit your manuscript here:
http://www.chemistrycentral.com/manuscript/

